\title{
Pigmented Nanoflagellates Grazing on Synechococcus: Seasonal Variations and Effect of Flagellate Size in the Coastal Ecosystem of Subtropical Western Pacific
}

\author{
Ya-Fan Chan • An-Yi Tsai • Kuo-Ping Chiang • \\ Chih-hao Hsieh
}

Received: 17 October 2008 / Accepted: 13 July 2009/Published online: 5 August 2009

(C) Springer Science + Business Media, LLC 2009

\begin{abstract}
We investigated seasonal variation of grazing impact of the pigmented nanoflagellates (PNF) with different sizes upon Synechococcus in the subtropical western Pacific coastal waters using grazing experiments with fluorescently labeled Synechococcus (FLS). For total PNF, conspicuous seasonal variations of ingestion rates on Synechococcus were found, and a functional response was observed. To further investigate the impact of different size groups, we separated the PNF into four categories $(<3,3-5$, $5-10$, and $>10 \mu \mathrm{m})$. Our results indicated that the smallest PNF $(<3 \mu \mathrm{m}$ PNF) did not ingest FLS and was considered autotrophic. PNF of 3-5 $\mu \mathrm{m}$ in size made up most of the PNF community; however, their ingestion on Synechococcus was too low $\left(0.1-1.9\right.$ Syn $\left.\mathrm{PNF}^{-1} \mathrm{~h}^{-1}\right)$ to support their growth, and they had to depend on other prey or photosynthesis to survive. The ingestion rate of the $3-5 \mu \mathrm{m}$ group exhibited no significant seasonal variation; by contrast, the ingestion rates of $5-10$ and $>10 \mu \mathrm{m}$ PNFs showed significant seasonal variation. During the warm
\end{abstract}

Y.-F. Chan

Institute of Marine Biology, National Taiwan Ocean University, Keelung 20224, Taiwan, Republic of China

A.-Y. Tsai $\cdot$ K.-P. Chiang

Institute of Environmental Biology and Fishery Science,

National Taiwan Ocean University,

Keelung 20224, Taiwan, Republic of China

K.-P. Chiang $(\bowtie)$

Institute of Marine Environmental Chemistry and Ecology,

National Taiwan Ocean University,

Keelung 20224, Taiwan, Republic of China

e-mail: KPChiang@mail.ntou.edu.tw

C.-h. Hsieh

Institute of Oceanography, National Taiwan University,

Taipei 10617, Taiwan, Republic of China season, 3-5 $\mu \mathrm{m}$ PNF were responsible for the grazing of $12 \%$ of Synechococcus production, 5-10 $\mu \mathrm{m}$ PNF for $48 \%$, and $>10 \mu \mathrm{m}$ PNF for $2 \%$. Taken together, our results demonstrate that the PNF of 3-10 $\mu \mathrm{m}$ consumed most Synechococcus during the warm season and exhibited a significant functional response to the increase in prey concentration.

\section{Introduction}

The factors controlling the fluctuations of Synechococcus have drawn much attention ever since their discovery. This single genus of autotrophic cyanobacteria makes up a large part of the picophytoplankton community in oligotrophic oceanic environments worldwide [30, 39, 40]. The genus is responsible for most of the photosynthesis occurring in the North Pacific Ocean [24]. Some studies have investigated the role of viral lysis and protozoan grazing on Synechococcus, and the results suggest that the impact of grazing processes is usually more important than viral lysis [6, 26, 32, 42]. Major grazers controlling the biomass and production of Synechococcus are ciliates and nanoflagellates, both phagotrophic protozoans [12, 14, 18, 19, 41]. Chen [8] reported that the rate of ingestion Synechococcus per ciliate was about two orders of magnitude higher than that per nanoflagellate. However, since the natural abundance of nanoflagellates is much higher than that of ciliates, grazing pressure on Synechococcus by the entire nanoflagellate community would be much higher than that by total ciliates. For example, in the North Pacific Ocean, the Synechococcus carbon consumed by nanoflagellates was around ten to 1,000 times that of the ciliates [43].

Caron et al. [7] reported that heterotrophic nanoflagellates (HNF) removed as much as $54 \%$ of Synechococcus 
biomass in the surface waters of the Sargasso Sea. Thus, heterotrophic nanoflagellates are likely to be the main player controlling the abundance of Synechococcus at least in some marine ecosystems. Pigmented nanoflagellates (PNF) consist of two major groups: autotrophic and mixotrophic nanoflagellates (MNF), with the latter being capable of photosynthesis and particle grazing [34]. In aquatic ecosystems, where PNF are dominant, PNF contribute significantly to bacterivory [8]. For example, Havskum \& Riemann [22], using the fluorescently labeled heat-killed bacteria technique, estimated that the feeding of PNF was responsible for up to $86 \%$ of the total bacterial grazing in some coastal environments. In some freshwater lakes, PNF have been found to remove more bacteria than either rotifers or ciliates [3]. However, only a few studies $[20,41]$ have investigated PNF grazing on picophytoplankton (Synechococcus). These studies reported PNF to be a major grazer of Synechococcus in marine system [20, 33, 41], but their results were of short duration and they used artificial, inert particles as tracers of prey ingestion.

At our study site along the coasts of the subtropical western Pacific, it was noted that the grazing of PNF had a significant impact on Synechococcus [41]. Moreover, Safi and Hall [33] reported that PNF had high grazing rates on picophytoplankton-size particles when PNF was dominant. However, these findings are contrary to Hall et al. [20], who observed an apparent preference for the bacteria-sized particles by PNF. The discrepancy may be explained by the observation that the preferred size ratio between predators and their prey is 3:1 for nanoflagellates [21]. That is, PNF with a smaller mean cell volume at $57 \mu^{3}$ would prefer to feed on smaller particles than do the HNF that have a larger mean cell volume of $74 \mu^{3}$. Nevertheless, if one considers PNF (or HNF) alone, does the size effect remain?

According to a previous study at our study site, Tsai et al. [41] identified PNF as the key grazers of Synechococcus populations in our coastal ecological system from May to October and showed that PNF grazed $40 \%$ to $86 \%$ of Synechococcus production. This study asserted that HNF of this size are too small to ingest particles of $\sim 1 \mu \mathrm{m}$. The authors also hypothesized that the grazing behavior of all members of the PNF community would be similar. However, considering the wide size range of PNF in the marine system, this hypothesis may be challenged. Indeed, to investigate the energy transfer in the complex marine microbial food web, we need better measurements of the feeding role played by PNF of different sizes.

In this context, the aims of the present study are (1) to investigate whether PNF of different sizes has a differential impact on the removal of Synechococcus in the coastal western Pacific Ocean and (2) to determine whether there are seasonal differences in the PNF grazing on Synechococcus. To carry out our study, we categorized PNF into different sizes and used the fluorescently labeled Synechococcus (FLS) technique to estimate their ingestion rates for the first 6 months (January-July 2005). We also used FLS to study seasonal variations of the grazing on Synechococcus by PNF that were not categorized by size for another 10 months (August 2005-October 2006). The seasonality of ingestion rates of protozoans may be influenced by different environmental and biological factors such as temperature, initial prey concentration, and light [2, 5, 15]; thus, we also attempted to identify which factors are more important in regulating the grazing behavior of $\mathrm{PNF}$.

\section{Materials and Methods}

\section{Study Site and Abundance Determinations}

Samples were collected at a coastal station $\left(25^{\circ} 09.4^{\prime} \mathrm{N}\right.$, $\left.121^{\circ} 46.3^{\prime} \mathrm{E}\right)$ off a rocky shore in northeastern Taiwan (Fig. 1). Based on background information collected from 1999 to 2001 in Tsai et al. [42], a seasonal oscillation in temperature was observed with higher temperatures $\left(>25^{\circ} \mathrm{C}\right)$ occurring in June to October, a time when nutrient concentrations were low $\left(\mathrm{NO}_{3}<1 \mu \mathrm{M} \mathrm{l}^{-1}\right)$. Annual salinity ranged from 33 to 34 with occasional drops below 33, probably caused by rain fall. To estimate the contribution of PNF to the consumption of Synechococcus, we collected samples of seawater once per month from 2005 to 2006. On each sampling day, seawater was collected from 09:00 to 10:00 in the morning (local time). We also collected samples from 20:00 to 22:00 at night (local time) from September 2005 to October 2006. Water temperature was measured immediately after the bucket cast. All samples were brought to the laboratory within $30 \mathrm{~min}$ after collection. In the period between January 2005 and October 2006, reported values of temperature and abundances of PNF and Synechococcus were averages of day and night measurements (Fig. 2).

Samples taken to measure Synechococcus and nanoplankton were fixed immediately after collection by adding glutaraldehyde to a final concentration of $1 \%(v / v)$. We filtered subsamples of Synechococcus (2 to $4 \mathrm{ml}$ ) and nanoflagellates $(20 \mathrm{ml})$ at low pressure $(<100 \mathrm{~mm} \mathrm{Hg})$ onto black Nuclepore filters $(0.2$ and $0.8 \mu \mathrm{m}$ for Synechococcus and nanoflagellates, respectively). A Millipore filter was used as a pad placed beneath the Nuclepore filter to ensure uniform distribution of cells. Cells left on filter membranes were stained with 4'6-diamidino-2-phenylindole (DAPI) at a final concentration of $1 \mu \mathrm{g} \mathrm{ml}^{-1}$ [31], and examined under epifluorescence microscopy at $\times 1,000$ (Nikon Optiphot-2). PNF were defined as cells that contained chloroplasts with red autofluorescence under blue excitation light. Autotrophic picoplankton (cyanobacteria Synechococcus) were collected on a Nuclepore filter without DAPI staining and 
Figure 1 Map illustrating the location of study site

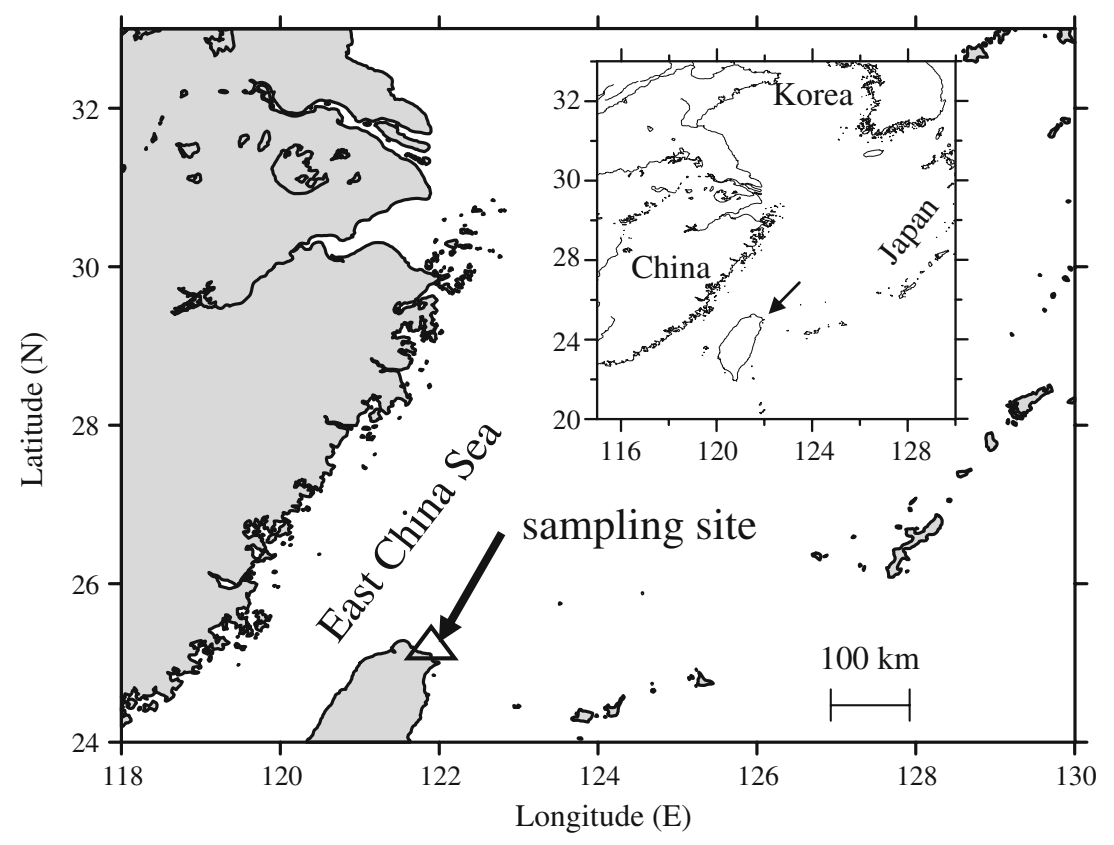

identified by their orange autofluorescence. To ensure reliability of the estimates, we counted the Synechococcus and PNF cells using 10 and 50 fields of view (average of 200 and 250 cells), respectively.

\section{Grazing Experiments}

Grazing rates of PNF on Synechococcus were estimated based on their ingestion of fluorescently labeled Synechococcus. Synechococcus (CH0129) was previously isolated from a surface water sample of northeastern Taiwan, and grown in $\mathrm{f} / 2$ media. FLS was stained with 5-(4,6-dichlorotriazin-2-yl) aminofluorescein according to the method described by Sherr and Sherr [38]. The mean size of the FLS was about $1 \mu \mathrm{m}$, similar to that of Synechococcus in situ. We distinguished the natural
Synechococcus from FLS by the bright green color from FLS under blue excitation light using epifluorescence microscopy.

In grazing experiments, which were done in triplicate, we filtered surface water samples though a $20 \mu \mathrm{m}$ nylon mesh into $500 \mathrm{ml}$ polycarbonate bottles and then added the tracer particles (FLS) to a concentration of $20 \%$ to $30 \%$ of the total counts of Synechococcus in the experiment bottle $[1,35]$ (Table 1). Bottles were incubated in a water bath at in situ temperature and light intensities. At $0,15,30,45$, and $60 \mathrm{~min}$ after the FLS was added, $20 \mathrm{ml}$ subsamples were preserved with glutaraldehyde (to $1 \% v / v$ final concentration). We counted PNF, Synechococcus, and FLS ingested by PNF under an epifluorescence microscope at $\times 1,000$ magnification. The nanoflagellate uptake rate on FLS was calculated by linear regression from the change of
Figure 2 Seasonal variation of Synechococcus abundance ( $10^{4}$ cells $\mathrm{ml}^{-1}$; shaded square), surface water temperature $\left({ }^{\circ} \mathrm{C}\right.$; shaded circle), and pigmented nanoflagellate (cells $\mathrm{ml}^{-1}$; unshaded circle) in 2005 and 2006. These values represent daily averages (error bars $= \pm 1$ standard deviation)

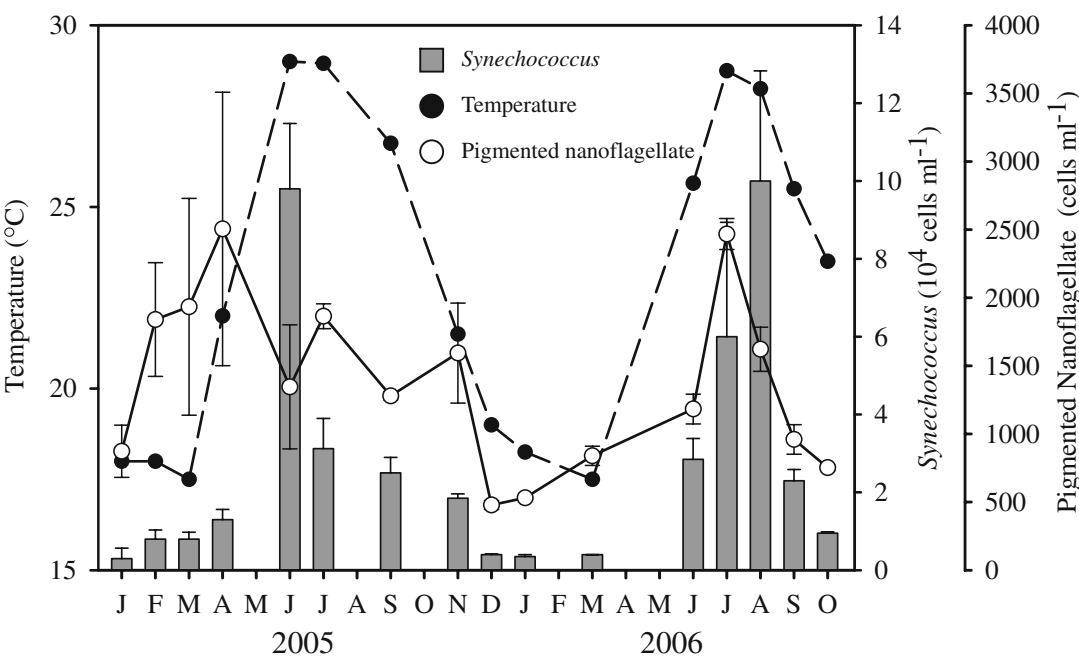


Table 1 Initial concentrations (cells $\mathrm{ml}^{-1}$ ) of Synechococcus, FLS, and PNF in the experimental bottles of grazing experiments

\begin{tabular}{|c|c|c|c|c|c|c|}
\hline & Date & E.T. $^{\mathrm{a}}$ & Synechococcus $\left(10^{4} \mathrm{ml}^{-1}\right)$ & FLS added $\left(\mathrm{ml}^{-1}\right)$ & FLS:syn ratio $(\%)$ & $\operatorname{PNF}\left(\mathrm{ml}^{-1}\right)$ \\
\hline \multirow[t]{13}{*}{2005} & January & Day & 0.3 & 781 & 28 & 873 \\
\hline & February & Day & 0.8 & 2,342 & 28 & 1,840 \\
\hline & March & Day & 0.8 & 2,774 & 35 & 1,934 \\
\hline & April & Day & 1.3 & 4,160 & 32 & 2,505 \\
\hline & June & Day & 9.8 & 21,570 & 22 & 1,346 \\
\hline & \multirow[t]{2}{*}{ July } & Day & 2.8 & 6,232 & 22 & 1,773 \\
\hline & & Night & 4.4 & 8,326 & 19 & 1,955 \\
\hline & \multirow[t]{2}{*}{ September } & Day & 2.1 & 7,140 & 34 & 1,309 \\
\hline & & Night & 2.9 & 9,280 & 32 & 1,251 \\
\hline & \multirow[t]{2}{*}{ November } & Day & 2 & 4,524 & 23 & 1,227 \\
\hline & & Night & 1.7 & 4,525 & 26 & 1,961 \\
\hline & \multirow[t]{2}{*}{ December } & Day & 0.4 & 1,450 & 38 & 446 \\
\hline & & Night & 0.4 & 916 & 26 & 511 \\
\hline \multirow[t]{14}{*}{2006} & \multirow[t]{2}{*}{ January } & Day & 0.3 & 1,028 & 35 & 523 \\
\hline & & Night & 0.4 & 1,110 & 28 & 540 \\
\hline & \multirow[t]{2}{*}{ March } & Day & 0.4 & 986 & 28 & 769 \\
\hline & & Night & 0.4 & 1,092 & 31 & 910 \\
\hline & \multirow[t]{2}{*}{ June } & Day & 2.3 & 3,501 & 15 & 1,292 \\
\hline & & Night & 3.4 & 4,767 & 14 & 1,074 \\
\hline & \multirow[t]{2}{*}{ July } & Day & 3 & 4,485 & 15 & 2,354 \\
\hline & & Night & 9 & 11,525 & 13 & 2,582 \\
\hline & \multirow[t]{2}{*}{ August } & Day & 7 & 16,908 & 24 & 1,784 \\
\hline & & Night & 13 & 33,027 & 26 & 1,460 \\
\hline & \multirow[t]{2}{*}{ September } & Day & 2 & 6,524 & 33 & 1,069 \\
\hline & & Night & 2.6 & 9,449 & 37 & 851 \\
\hline & \multirow[t]{2}{*}{ October } & Day & 1 & 3,476 & 35 & 775 \\
\hline & & Night & 0.9 & 3,035 & 33 & 730 \\
\hline
\end{tabular}

FLS fluorescently labeled Synechococcus, PNF pigmented nanoflagellate

${ }^{a}$ Experiment time: day time, 09:00 to 10:00; night time, 20:00 to 22:00

average number of FLS $\mathrm{PNF}^{-1}$ over time [37, 41]. Normally, when we calculated the FLS PNF${ }^{-1}$ over time, we used every time point to make a linear regression. In some cases, the uptake of FLS saturated after $30 \mathrm{~min}$ and we used the first three time points $(0,15$, and $30 \mathrm{~min})$ to calculate the uptake rate on FLS by linear regression. The ingestion rate $\left(\operatorname{Syn} \mathrm{PNF}^{-1} \mathrm{~h}^{-1}\right)$ was then estimated from the ratio between concentration of FLS and abundance of Synechococcus in the incubation bottle (Table 1). To compare loss of Synechococcus with its production, we estimated consumption rates $\left(\right.$ Syn $\left.\mathrm{ml}^{-1} \mathrm{~h}^{-1}\right)$ by multiplying ingestion rates on Synechococcus and total PNF per milliliter. To estimate the ingestion rate of PNF belonging to different size classes on Synechococcus, we divided PNF into four size categories: $<3,3-5,5-10$, and $>10 \mu \mathrm{m}$, and recorded their FLS content separately from January to July 2005.

The method of ANOVA was used for testing the significance of seasonal variation of the abundance of
Synechococcus and PNF, and ingestion rate and consumption rate of PNF. The simple linear regression analyses between grazing rate of PNF and prey abundance or water temperature were performed to determine the controlling factor of grazing rate of PNF. Next, we used multivariate regression analysis to find out which factor (prey abundance or water temperature) was a major controlling factor of the ingestion rates of four different sizes of PNF. Specifically, we normalized variables to unit mean and variance so that the temperature and Synechococcus abundance are directly comparable; we then calculated the beta weights for the prey abundance and water temperature and determined the relative contribution of the two factors [27]. All analyses were conducted using SPSS software.

The size composition of PNF was calculated as the percentage of each size classes in the whole PNF community (Fig. 4a). In addition, the size composition of FLS-containing PNF was calculated by dividing the 
number of FLS-containing PNF in each size class by the number of FLS-containing PNF (Fig. 4b). To avoid underestimation of the percentage of mixotrophic organisms in the PNF community, we calculated the percentage of PNF that ingested the FLS during our grazing experiments according to Poisson EZ method [4].

\section{Results}

Water Temperature, PNF, and Synechococcus Abundance

The water temperature exhibited a regular seasonal pattern with high values in summer and low values in winter, and the Synechococcus abundance closely tracked this seasonality (Fig. 2). The monthly water temperatures varied from $17^{\circ} \mathrm{C}$ (March) to $29^{\circ} \mathrm{C}$ (July; Fig. 2). The monthly Synechococcus abundance ranged from $0.3 \times 10^{4}$ to $10 \times 10^{4} \mathrm{cells} \mathrm{ml}^{-1}$ and reflected the seasonal temperature changes $\left(r^{2}=0.64\right.$, $p<0.05$ ) with the highest values (about $10 \times 10^{4}$ cells $\mathrm{ml}^{-1}$ ) in June 2005 and August 2006 and the lowest values $(0.3 \times$ $10^{4}$ cells $\mathrm{ml}^{-1}$ ) in January 2005 and 2006 (Fig. 2). PNF abundance, however, did not follow temperature $\left(r^{2}=0.19\right.$, $p>0.05$ ) and exhibited different seasonal variations in these 2 years. The highest (about 2,500 cells ml${ }^{-1}$ ) values were found in April 2005 and July 2006, about 1 or 2 months before the highest density of Synechococcus (June 2005; Fig. 2), and the low values were found in December 2005 and January 2006 (about 500 cells ml $^{-1}$ ).

\section{Grazing Experiments}

Using FLS to measure ingestion, we provided the first estimates of seasonal impacts of PNF grazing upon Synechococcus in the coastal waters of the western subtropical Pacific Ocean. In our study (Table 1), no significant difference was found between the day and night experiments (paired $t$ test, $p=0.77$ ) so that the average values were presented (Fig. 3b). The magnitudes and trends of PNF ingestion rate were different in 2005 and 2006 (Fig. 3a). In 2005, ingestion rates increased from January to July, leveled off between July and September, and increased again in November. In 2006, an obvious seasonal variation was observed. The highest ingestion rates appeared in summer (0.83 Syn $\mathrm{PNF}^{-1} \mathrm{~h}^{-1}$, August 2006), and the lowest rate was in October $\left(0.08\right.$ Syn $\left.\mathrm{PNF}^{-1} \mathrm{~h}^{-1}\right)$. Moreover, the consumption rate (i.e. the total Synechococcus ingested by PNF) followed a pattern similar to that of the ingestion rate of PNF, with the highest rate occurring in August 2006 $\left(1.1 \times 10^{3}\right.$ Syn $\left.\mathrm{ml}^{-1} \mathrm{~h}^{-1}\right)$ and the lowest in December 2005 $\left(0.045 \times 10^{3}\right.$ Syn $\mathrm{ml}^{-1} \mathrm{~h}^{-1}$; Fig. 3a).

Size compositions of PNF varied through time and so did the ingestion pattern of different size groups (Fig. 4). At
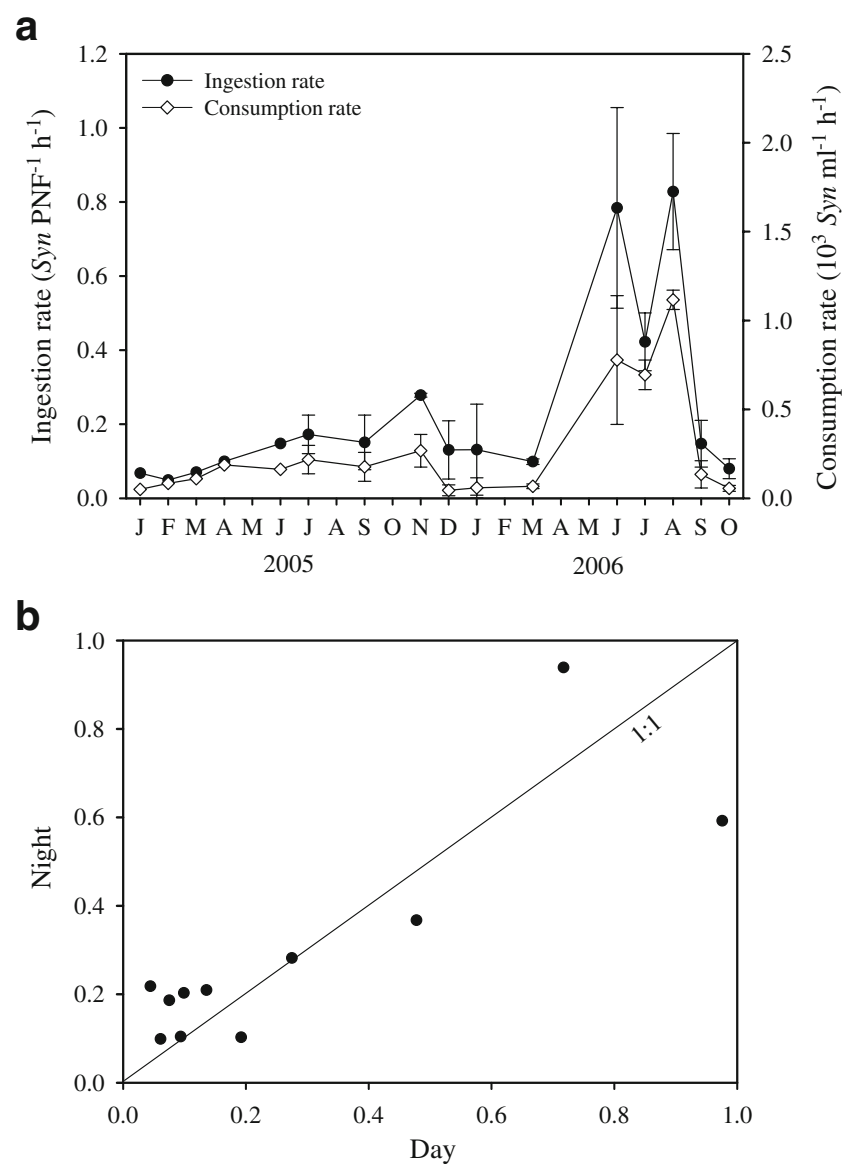

Figure 3 a Time series of ingestion rate $\left(S y n \mathrm{PNF}^{-1} \mathrm{~h}^{-1}\right)$ and consumption rate $\left(10^{3}\right.$ Syn $\left.\mathrm{ml}^{-1} \mathrm{~h}^{-1}\right)$ of PNF. Error bars $= \pm 1$ standard deviation and $\mathbf{b}$ scatter plot illustrating the relationship between day and night ingestion rates of PNF. The diagonal line indicates the 1:1 relationship

our study site, there was a high abundance of 3-5 $\mu \mathrm{m}$ PNF over the entire study period (ranging from of $45 \%$ to $70 \%$ and with an average of $62 \%$; Fig. 4a). The smallest PNF (cells $<3 \mu \mathrm{m}$ ) was composed of the unidentified unicellular organisms and contributed to between $7 \%$ and $30 \%$ of the total PNF (Fig. 4a). No PNF within this size range was found to ingest FLS in our incubation experiments. The 3-5 $\mu \mathrm{m}$ fraction made up most of the FLScontaining PNF (Fig. 4b). PNF $>10 \mu \mathrm{m}$ appeared during the summer period, and their contribution to the grazing on FLS clearly increased during this time (Fig. 4b). Based on the Poisson EZ method [4], we estimated the percentage of the active grazer in PNF as only $1.3 \%$ to $3.8 \%$ (mean $2.35 \%$ ).

As for grazing effect, the ingestion rates of 3-5 $\mu \mathrm{m}$ PNF remained low (0.1-1.9 Syn $\mathrm{PNF}^{-1} \mathrm{~h}^{-1}$ ) from January to July (Fig. 5a). In June, there was a marked fluctuation in abundance of PNF of sizes between 5-10 and $>10 \mu \mathrm{m}$. At that time, the ingestion rates associated with these two size categories reached their maximum (14 and 12 Syn $\mathrm{PNF}^{-1} \mathrm{~h}^{-1}$, 

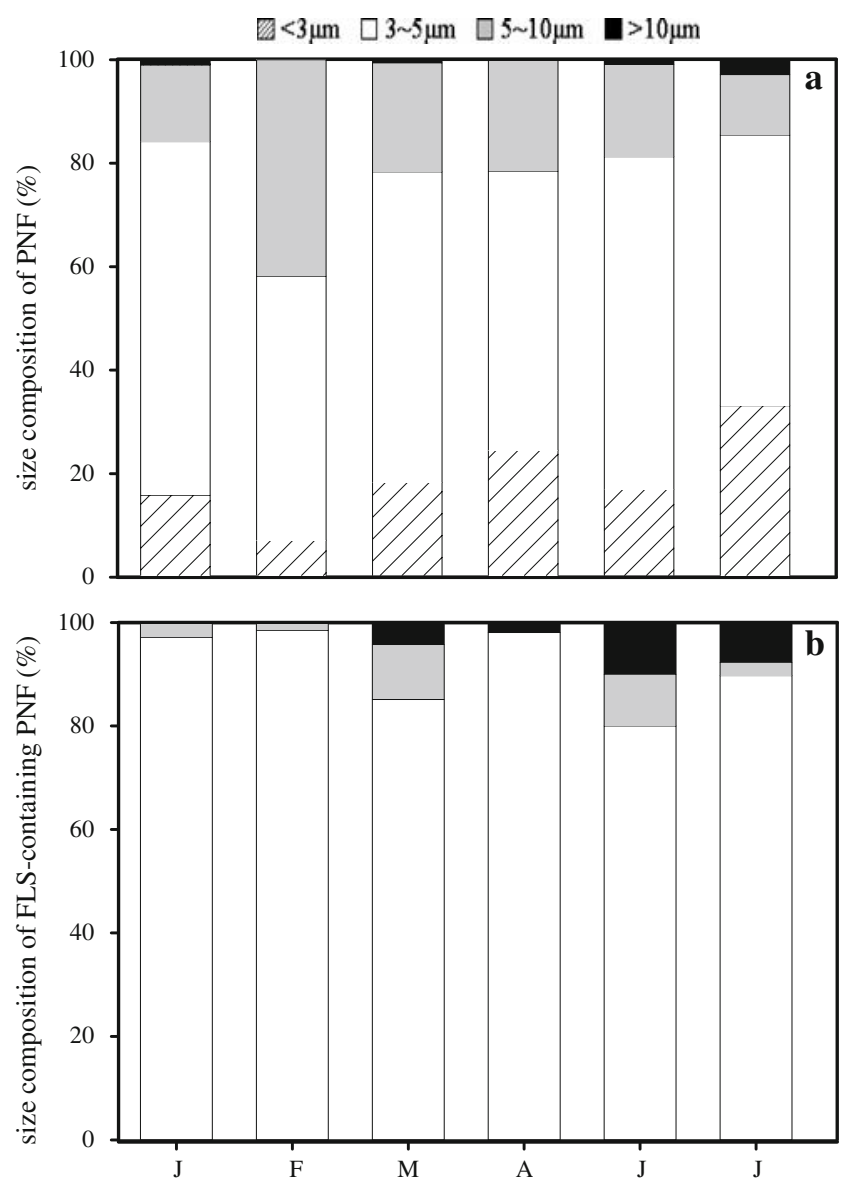

Figure 4 a The percentage of PNF belonging to four different size categories $(<3,3-5,5-10$, and $>10 \mu \mathrm{m})$ and $\mathbf{b}$ the percentage of total FLS-containing PNF in the four categories from January to July 2005

respectively; Fig. 5a). Moreover, the ingestion rate of PNF 5-10 $\mu \mathrm{m}$ and PNF $>10 \mu \mathrm{m}$ was two- to sixfold higher, respectively, in June and July than in January to April. Multiplying the ingestion rate by the number of each size PNF per milliliter generated the consumption rate for each size of PNF on Synechococcus. Except for January and April, PNF 5-10 $\mu \mathrm{m}$ had a greater consumption rate (range, $1.25 \times 10^{3}$ to $3.43 \times 10^{3}$ Syn $\mathrm{ml}^{-1} \mathrm{~h}^{-1}$ ) than did other PNF size categories (range, $3-5 \mu \mathrm{m}: 0.36 \times 10^{3}$ to $0.85 \times 10^{3}$ Syn $\mathrm{ml}^{-1} \mathrm{~h}^{-1}$ and $>10 \mu \mathrm{m}: 0.08 \times 10^{3}$ to $0.15 \times$ $10^{3}$ Syn $\mathrm{ml}^{-1} \mathrm{~h}^{-1}$; Fig. 5b). The largest size PNF $(>10 \mu \mathrm{m})$ made up only about $3 \%$ of the total PNF abundance (Fig. 4a); therefore, its consumption of Synechococcus was generally low $\left(<0.5 \times 10^{3}\right.$ Syn $\mathrm{ml}^{-1} \mathrm{~h}^{-1}$; Fig. $\left.5 \mathrm{~b}\right)$. With the exception of April, PNF 5-10 $\mu \mathrm{m}$ were responsible for $52 \%$ to $86 \%$ of the grazing on Synechococcus (Fig. 6), and PNF $>10 \mu \mathrm{m}$ accounted for relatively low percentage (ranged from $1 \%$ to $5 \%$; Fig. 6). For the whole study period (January to July 2005), 3-5 $\mu \mathrm{m}$ PNF and 5-10 $\mu \mathrm{m}$ PNF were responsible for, on average, $40 \%$ and $58 \%$ of the grazing, respectively (Fig. 6).

\section{Discussion}

We studied the mechanisms behind seasonal variations in PNF grazing on Synechococcus in subtropical western Pacific coastal waters. In a previous study, Chen [9] reported that the entire ciliate community removed $\sim 3 \%$ of Synechococcus production per day in spite of high ingestion rate being observed for individual ciliates. Furthermore, Tsai et al. [41] found that HNF was practically incapable of grazing Synechococcus, and demonstrated the important role played by the PNF in the regulation of Synechococcus. However, we found that not all PNF contributed to mixotrophy (Fig. 4b). Our results indicate that the smallest PNF $(<3 \mu \mathrm{m}$ PNF) was possibly autotrophic as they did not ingest any fluorescently labeled Synechococcus (Fig. 4b). This finding is consistent with a previous study [44] that observed no ingestion of fluorescence-labeled bacteria by $\mathrm{PNF}<3 \mu \mathrm{m}$ in size. For larger size groups $(3-5,5-10$, and $>10 \mu \mathrm{m})$, we did find
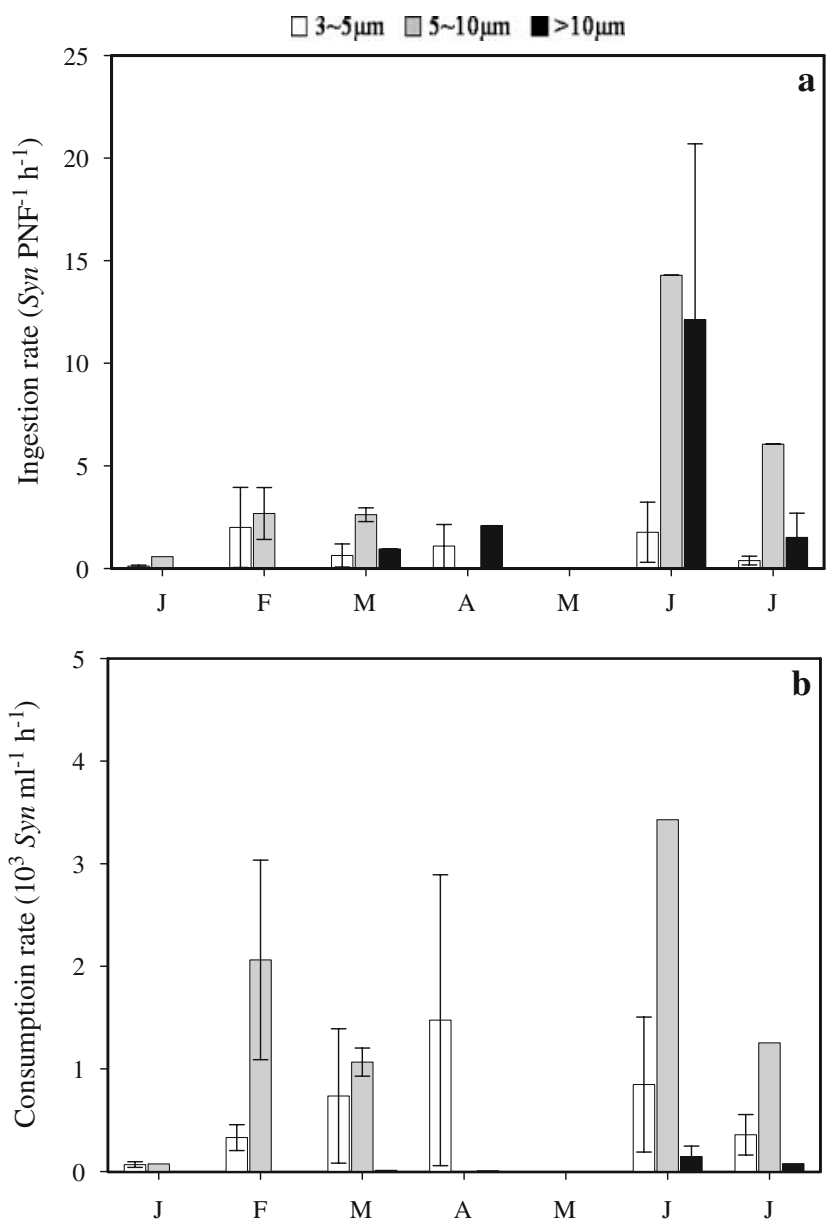

Figure 5 a The ingestion rates $\left(S y n \mathrm{PNF}^{-1} \mathrm{~h}^{-1}\right)$ and $\mathbf{b}$ consumption rates $\left(10^{3}\right.$ Syn $\left.\mathrm{ml}^{-1} \mathrm{~h}^{-1}\right)$ of PNF in three different size categories (3-5, 5-10, and $>10 \mu \mathrm{m}$ ) from January to July 2005. Error bars $= \pm 1$ standard deviation 


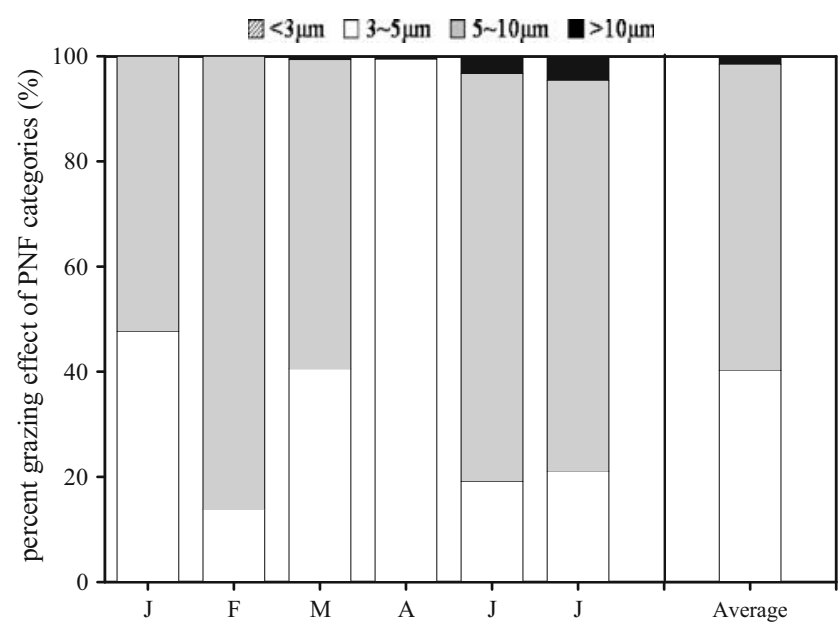

Figure 6 The percentage grazing effect (\%) of PNF in three different size categories $(3-5,5-10$, and $>10 \mu \mathrm{m})$ from January to July 2005

that they occupied a major portion $(60 \%$ to $92 \%)$ in PNF, and were able to ingest FLS (Fig. 4a). It has been reported that around $2 \%$ to $38 \%$ of PNF are mixotrophic in the Georges Bank and $9 \%$ to $49 \%$ in the Bay of Aarhus, respectively $[22,35]$. A higher proportion of mixotrophs $(53 \%)$ has also been reported for surface waters of the Sargasso Sea [1]. Based on these results, it seems that the phagotrophic PNF exerts a significant grazing effect on bacteria. In our study, the portion of Synechococcus-feeding MNF (active grazers feeding on FLS) varied between 1.3\% and $3.8 \%$ of total PNF as estimated by the Poisson EZ method [4]. This range was much lower than values reported in other studies [1, 20,33]. Both Safi and Hall [33] and Hall et al. [20] used the picophytoplankton size beads in their measurements, and observed 57\% and $>50 \%$ of PNF were mixotrophic, respectively. In addition, Arenovski et al. [1] found $50 \%$ of PNF containing ingested FLS. Although these studies did not use Poisson EZ method to correct their estimates of Synechococcus-feeding MNF, these estimates still represent higher values.

The prey type may cause the difference in percentages of Synechococcus-feeding MNF. For example, fluorescently labeled beads cannot be digested but FLS can. It is possible that the digestion of FLS was very fast and caused underestimation of active grazer on FLS [4]. However, the percentage of active grazers did not significantly increase when fluorescently labeled beads (diameter $1 \mu \mathrm{m}$ ) were used as food particles (Chan, unpublished result). Gonzãlez et al. [16] reported that HNF in eutrophic systems contained higher percentages of active grazers than does HNF in oligotrophic system. The low percentages of Synechococcus-feeding MNF at our study site may represent a characteristic of the particular ecosystem.
Grazing Impact of PNF

The impact of community consumption of PNF on Synechococcus biomass varied from $14 \%$ to $53 \%$ per day (mean 29\%) in this study, which is consistent with previous studies $[6,11,25,33,35]$. Generally, the grazing pattern of PNF was mainly affected by temperature and the availability of food. In our study, we found that the ingestion rates of total PNF were linearly correlated with water temperatures and the abundance of Synechococcus $\left(r^{2}=0.49\right.$ and 0.94 respectively, $p<0.05$; Table 2 ). However, based on comparisons of beta weight $\left(t_{1}\right.$ and $\left.t_{2}\right)$ in multivariate regression analysis [27], we found that the Synechococcus abundance was a stronger factor in controlling the ingestion rates of PNF than temperature (Table 2).

The ingestion rate responding to prey availability can be described as a functional response [10, 11, 23, 29]. Several studies suggested that the ingestion rates of HNF increase linearly with the increase in picoplankton concentrations [7, $11,13]$, which has been characterized as type I functional response. Most studies showed that the ingestion rates of HNF on bacteria or Synechococcus represented a type I functional response, although Grover [17] used heterotrophic microflagellate feeding experiments in laboratory cultures and showed a clear saturating type II functional response for two species of diatom. In our study, ingestion by PNF was not the saturated type but rather linear (functional response I; Table 2). This is the first study to report in situ evidence that PNF functionally responds to abundance of Synechococcus.

Ingestion rates measured at our study site were somewhat higher than published values. To some extent, our results should be closer to the true ingestion rate in natural environments because stained Synechococcus instead of latex beads were used as food particles. There is evidence to indicate that nanoflagellates ingest Synechococcus more actively [28, 36]. However, a minor overestimation may exist in our results. Since the Synechococcus that we used to produce FLS were grown in nutrient-sufficient conditions, this kind of highquality food may induce higher ingestion rates [36]. Also, the addition of FLS inevitably increased food concentrations for flagellates in our experiments [28], which may cause overestimation according to the functional response defined by our multiple regression analysis (ingestion rate $=0.009$ temperature+0.039 Syn-0.058). In our experiments, the addition of FLS was carefully controlled to about $20 \%$ of the natural abundance of Synechococcus, which translates to an overestimation between $5 \%$ and $15 \%$ when the temperature range is set from $20^{\circ} \mathrm{C}$ to $25^{\circ} \mathrm{C}$ and the range of Synechococcus abundance is set from $10^{4}$ to $10^{5}$ cells ml ${ }^{-1}$.

At our study site, nutrient concentration was low $\left(\mathrm{NO}_{3}<1 \mu \mathrm{M} \mathrm{l}^{-1}\right)$ between June and October [42]. Phagotrophic behavior may be necessary for these PNF to obtain 
Table 2 Correlations and beta weights of multivariate regressions between predator (all PNF community, $<3,3-5,5-10$, and $>10 \mu \mathrm{m}$ ) and surface water temperature $\left({ }^{\circ} \mathrm{C}\right)$ and Synechococcus abundance $\left(10^{4}\right.$ cells $\left.\mathrm{ml}^{-1}\right)$

\begin{tabular}{|c|c|c|c|c|c|c|c|c|}
\hline \multirow[t]{2}{*}{ Ingestion rate $\left(\operatorname{Syn} \mathrm{PNF}^{-1} \mathrm{~h}^{-1}\right)$} & \multicolumn{4}{|c|}{ Temperature } & \multicolumn{4}{|c|}{ Synechococcus } \\
\hline & $r^{2}$ & $p$ & $t_{1}^{\mathrm{a}}$ & $n$ & $r^{2}$ & $p$ & $t_{2}^{\mathrm{b}}$ & $n$ \\
\hline Total PNF & 0.24 & $<0.01$ & $0.233^{\mathrm{c}}$ & 27 & 0.34 & $<0.001$ & $0.767^{\mathrm{c}}$ & 27 \\
\hline 3-5 $\mu \mathrm{m}$ PNF & 0.01 & $>0.05$ & & 15 & 0.02 & $>0.05$ & & 15 \\
\hline 5-10 $\mu \mathrm{m}$ PNF & 0.59 & $>0.05$ & & 15 & 0.93 & $<0.01$ & & 15 \\
\hline$>10 \mu \mathrm{m}$ PNF & 0.93 & $<0.05$ & $0.139^{\mathrm{d}}$ & 15 & 0.97 & $<0.001$ & $0.861^{\mathrm{d}}$ & 15 \\
\hline
\end{tabular}

$P N F$ pigmented nanoflagellate

${ }^{\mathrm{a}} t_{1}=\left(b_{1} /\left(b_{1}+b_{2}\right)\right)$

${ }^{\mathrm{b}} t_{2}=\left(b_{2} /\left(b_{1}+b_{2}\right)\right)$

${ }^{\mathrm{c}}$ After multiple regression, beta $=0.146\left(b_{1}\right), p=0.533$ (temperature); beta $=0.48\left(b_{2}\right), p=0.049($ Syn $), R^{2}=0.35$

${ }^{\mathrm{d}}$ After multiple regression, beta $=0.182\left(b_{1}\right), p=0.26$ (temperature); beta $=1.123\left(b_{2}\right), p=0.003($ Syn $), R^{2}=0.98$

essential nutrient for growth. Mixotrophs with this growth strategy would be expected to respond favorably to increasing prey abundance.

\section{Differences in Grazing Patterns Between the PNF Size Classes}

Among different size groups of PNF (3-5, 5-10, and $>10 \mu \mathrm{m}$ ), we found that about $90 \%$ of the FLS-containing PNF at our study site was attributed to $3-5 \mu \mathrm{m}$ PNF (Fig. 4b). However, their per capita ingestion rate remained low throughout the study period (0.1-1.9Syn $\mathrm{PNF}^{-1} \mathrm{~h}^{-1}$; Fig. 5a). Considering that 3-5 $\mu \mathrm{m}$ PNF had a high abundance but showed the lowest ingestion rate on Synechococcus in warmer months, we speculate that PNF of this size class may rely on other prey or autotrophy for their supply of nutrients to remain abundant and maintain their dominance in the PNF community (Fig. 4a). One possible alternative food source is bacteria, as Unrein et al. [44] found that the $<5 \mu \mathrm{m}$ PNF made up most bacterivory nanoflagellates (ranging from 19\% to $61 \%$ ) throughout the year in an oligotrophic coastal system. However, we did not estimate PNF bacterivory in this study and further studies are needed.

We examined the grazing effects of 5-10 and $>10 \mu \mathrm{m}$ PNF on Synechococcus and found that their grazing patterns had a noticeable seasonality, higher during the warmer months (Fig. 5a). The ingestion rate of PNF $5-10 \mu \mathrm{m}$ was significantly correlated with the abundance of Synechococcus $\left(r^{2}=0.93, p<0.01\right)$ but not temperature, while the ingestion rate of PNF $>10 \mu \mathrm{m}$ was significantly correlated with the abundance of Synechococcus and water temperature (Table 2). However, using multivariate regression to calculate beta weights of Synechococcus abundance and temperature factors, we found that Synechococcus abundance $\left(t_{2}=0.861\right)$ played a greater role in influencing the PNF ingestion rates than water temperature $\left(t_{1}=0.139\right.$; Table 2). These results suggest that Synechococcus is an important energy source for 5-10 and $>10 \mu \mathrm{m}$ PNF in the coastal waters of western subtropical Pacific Ocean.

Christaki et al. [11] assembled the ingestion rates of HNF in various environments and showed that the ingestion rates range from 0.008 to $0.5 \mathrm{Syn}$ flagellate ${ }^{-1} \mathrm{~h}^{-1}$. To our knowledge, no studies have estimated the grazing rates on picophytoplankton (Synechococcus) by the PNF. Some studies used beads $(1 \mu \mathrm{m})$ similar to Synechococcus in size to measure the ingestion rates of PNF, and obtained 0.02 and 0.04 beads $\mathrm{PNF}^{-1} \mathrm{~h}^{-1}$ in the coastal area and open ocean, respectively $[20,33]$. Compared with these studies, the ingestion rates at our study site were relatively high, with 5-10 $\mu \mathrm{m}$ PNF ingesting as much as 14 Syn $\mathrm{PNF}^{-1} \mathrm{~h}^{-1}$ (Fig. 5a). This discrepancy suggests the importance in subcategorizing PNF grazers according to size in order to estimate the grazing parameters in microbial food webs.

Our study provided a better understanding of trophic structures and the energy flow within the microbial loop. To show this, we compared the growth rates of Synechococcus in 2005 (Tsai, unpublished data) with the grazing rates $(>3 \mu \mathrm{m}$ PNF) of our study. The growth rate of Synechococcus was higher in the warmer months, amounting to 4,900 Syn $\mathrm{ml}^{-1} \mathrm{~h}^{-1}$. Comparing the production rate of Synechococcus with the grazing rates of different PNF size categories, we found that 3-5 $\mu \mathrm{m}$ PNF were responsible for ingesting 12\% of Synechococcus production, 5-10 $\mu \mathrm{m}$ PNF for $48 \%$ and $>10 \mu \mathrm{m}$ PNF for $2 \%$. By contrast, another study at the same site indicated that ciliates accounted for the removal of only about $3 \%$ of Synechococcus production [9]. Thus, about $60 \%$ of Synechococcus production loss was attributable to PNF in size of 3-10 $\mu \mathrm{m}$. If we correct for the overestimation of ingestion rates of each category PNF, it would still be about 58\% of Synechococcus production. 
While recent studies have demonstrated the importance of PNF as phagotrophs in marine ecosystems [22, 35, 41, 44], there are limited data on the grazing impact of mixotrophic populations upon picophytoplankton [33, 35, 41]. Our study demonstrated that the PNF of different sizes showed significant variations in their grazing patterns on Synechococcus in the subtropical western Pacific.

Acknowledgments This study was supported by a grant from the National Science Council, ROC (NSC 91-2313-B-019-031) and a grant from the Center for Marine Bioscience and Biotechnology at NTOU. We are most grateful to Dr. Jeng Chang of Institute of Marine Biology of National Taiwan Ocean University for his language editing and comments on the manuscript.

\section{References}

1. Arenovski AL, Lim EL, Caron DA (1995) Mixotrophic nanoplankton in oligotrophic surface waters of the Sargasso Sea may employ phagotrophy to obtain major nutrients. J Plankton Res 17:801-820

2. Armbrust EV, Bowen JD, Olson RJ, Chisholm SW (1989) Effect of light on the cell cycle of a marine Synechococcus strain. Appl Environ Microbiol 55:425-432

3. Bird DF, Kalff J (1987) Algal phagotrophy: regulating factors and importance relative to photosynthesis in Dinobryon (Chrysophyceae). Limnol Oceanogr 32:277-284

4. Bratvold D, Srienc F, Taub SR (2000) Analysis of the distribution of ingested bacteria in nanoflagellates and estimation of grazing rates with flow cytometry. Aquat Microb Ecol 21:1-12

5. Burney CM, Davis PG, Johnson KM, Sieburth JMN (1982) Diel relationships of microbial trophic groups and in situ dissolved carbohydrate dynamics in the Caribbean Sea. Mar Biol 67:311-322

6. Caron DA, Lim EL, Miceli G, Waterbury JB, Valois FW (1991) Grazing and utilization of chroococcoid cyanobacteria and heterotrophic bacteria by protozoa in laboratory cultures and a coastal plankton community. Mar Ecol Prog Ser 76:205-217

7. Caron DA, Peele ER, Lim EL, Dennett MR (1999) Picoplankton and nanoplankton and their trophic coupling in surface waters of the Sargasso Sea south of Bermuda. Limnol Oceanogr 44:259-272

8. Caron DA, Porter KG, Sanders RW (1990) Carbon, nitrogen, and phosphorus budgets for the mixotrophic phytoflagellate Poterioochromonas malhamensis (Chrysophyceae) during bacterial ingestion. Limnol Oceanogr 35:433-443

9. Chen KM (2003) Ciliate grazing on Synechococcus in a coastal and shelf marine ecosystem: spatial-temporal variations and importance to biological carbon cycling. PhD dissert, Institute of Marine Biology, National Taiwan Ocean University, Taiwan, Republic of China, unpublished

10. Cho BC, Na SC, Choi DH (2000) Active ingestion of fluorescently labeled bacteria by mesopelagic heterotrophic nanoflagellates in the East Sea, Korea. Mar Ecol Prog Ser 206:23-32

11. Christaki U, Courties C, Karayanni H, Giannakourou A, Maravelias C, Kormas KA, Lebaron P (2002) Dynamic characteristics of Prochlorococcus and Synechococcus consumption by bacterivorous nanoflagellates. Microb Ecol 43:341-352

12. Christaki U, Jacquet S, Dolan JR, Vaulot D, Rassoulzadegan F (1999) Growth and grazing on Prochlorococcus and Synechococcus by two marine ciliates. Limnol Oceanogr 44:52-61

13. Dolan JR, Šimek K (1999) Diel periodicity in Synechococcus populations and grazing by heterotrophic nanoflagellates: analysis of food vacuole contents. Limnol Oceanogr 44:1565-1570
14. Dolan JR, Šimek K (1998) Ingestion and digestion of an autotrophic picoplankter, Synechococcus, by a heterotrophic nanoflagellate, Bodo saltans. Limnol Oceanogr 43:1740-1746

15. Felip M, Pace ML, Cole JJ (1996) Regulation of planktonic bacterial growth rates: the effects of temperature and resources. Microb Ecol 31:15-28

16. Gonzãlez JM (1999) Bacterivory rate estimates and fraction of active bacterivores in natural protist assemblages from aquatic systems. Appl Environ Microbiol 65:1463-1469

17. Grover JP (1990) Grazing by a heterotrophic microflagellate on two diatoms: functional and numerical responses in laboratory cultures. Archiv fur Hydrobiologie 119:197-214

18. Guillou L, Jacquet S, Chretiennot-Dinet MJ, Vaulot D (2001) Grazing impact of two small heterotrophic flagellates on Prochlorococcus and Synechococcus. Aquat Microb Ecol 26:201-207

19. Hadas O, Malinsky-Rushansky N, Pinkas R, Cappenberg TE (1998) Grazing on autotrophic and heterotrophic picoplankton by ciliates isolated from Lake Kinneret, Israel. J Plankton Res 20:1435-1448

20. Hall JA, Barrett DP, James MR (1993) The importance of phytoflagellate, heterotrophic flagellate and ciliate grazing on bacteria and picophytoplankton sized prey in a coastal marine environment. J Plankton Res 15:1075-1086

21. Hansen B, Bjørnsen PK, Hansen PJ (1994) The size ratio between planktonic predators and their prey. Limnol Oceanogr 39:395-403

22. Havskum H, Riemann B (1996) Ecological importance of bacterivorous, pigmented flagellates (mixotrophs) in the Bay of Aarhus, Denmark. Mar Ecol Prog Ser 137:251-263

23. Ichinotsuka D, Ueno H, Nakano S (2006) Relative importance of nanoflagellates and ciliates as consumers of bacteria in a coastal sea area dominated by oligotrichous Strombidium and Strobilidium. Aquat Microb Ecol 42:139-147

24. Iturriaga R, Mitchell BG (1986) Chroococcoid cyanobacteria: a significant component in the food web dynamics of the open ocean. Mar Ecol Prog Ser 28:291-297

25. James MR, Hall JA, Barrett DP (1996) Grazing by protozoa in marine coastal and oceanic ecosystems of New Zealand. NZ J Mar Freshwat Res 30:313-324

26. Johnson PW, Huai-Shu X, Sieburth JM (1982) The utilization of chroococcoid cyanobacteria by marine protozooplankters but not by calanoid copepods. Ann Inst Oceanogr Paris Nouv Ser 58:297308

27. Lewis-Beck DMS (1980) Applied regression: an introduction. Sage, Washington, DC

28. McManus GB, Okubo A (1991) On the use of surrogate food particles to measure protistan ingestion. Limnol Oceanogr 36:613-617

29. Menon P, Becquevort S, Billen G, Servais P (1996) Kinetics of flagellate grazing in the presence of two types of bacterial prey. Microb Ecol 31:89-101

30. Partensky F, Blanchot J, Vaulot D (1999) Differential distribution and ecology of Prochlorococcus and Synechococcus in oceanic waters: a review. Bull Inst Océanogr Monaco Numero Spec. 19:431-449

31. Porter KG, Feig YS (1980) The use of DAPI for identifying and counting aquatic microflora. Limnol Oceanogr 25:943-948

32. Proctor LM, Fuhrman JA (1990) Viral mortality of marine bacteria and cyanobacteria. Nature 343:60-62

33. Safi KA, Hall JA (1999) Mixotrophic and heterotrophic nanoflagellate grazing in the convergence zone east of New Zealand. Aquat Microb Ecol 20:83-93

34. Sanders R (1991) Trophic strategies among heterotrophic flagellates. In: Larsen DJPJ (ed) The biology of heterotrophic flagellates. Clarendon, Oxford, pp 21-38

35. Sanders RW, Berninger UG, Lim EL, Kemp PF, Caron DA (2000) Heterotrophic and mixotrophic nanoplankton predation on pico- 
plankton in the Sargasso Sea and on Georges Bank. Mar Ecol Prog Ser 192:103-118

36. Shannon SP, Chrzanowski TH, Grover JP (2007) Prey food quality affects flagellate ingestion rates. Microb Ecol 53:66-73

37. Sherr BF, Sherr EB, Pedros-Alio C (1989) Simultaneous measurement of bacterioplankton production and protozoan bacterivory in estuarine water. Mar Ecol Prog Ser 54:209-219

38. Sherr EB, Sherr BF (1993) Protistan grazing rates via uptake of fluorescently labeled prey. Handbook of Methods in Aquatic Microbial Ecology 695-701

39. Stockner JG (1988) Phototrophic picoplankton: an overview from marine and freshwater ecosystems. Limnol Oceanogr 33:765-775

40. Stockner JG, Antia NJ (1986) Algal picoplankton from marine and freshwater ecosystems: a multidisciplinary perspective. Can J Fish Aquat Sci 43:2472-2503
41. Tsai AY, Chiang KP, Chan YF, Lin YC, Chang J (2007) Pigmented nanoflagellates in the coastal western subtropical Pacific are important grazers on Synechococcus populations. J Plankton Res 29:71-77

42. Tsai AY, Chiang KP, Chang J, Gong GC (2005) Seasonal diel variations of picoplankton and nanoplankton in a subtropical western Pacific coastal ecosystem. Limnol Oceanogr 50:1221-1231

43. Tsai AY, Chiang KP, Chang J, Gong GC (2008) Seasonal variations in trophic dynamics of nanoflagellates and picoplankton in coastal water of the western subtropical Pacific. Aquat Microb Ecol 51:263274

44. Unrein F, Massana R, Alonso-Sáez L, Gasol JM (2007) Significant year-round effect of small mixotrophic flagellates on bacterioplankton in an oligotrophic coastal system. Limnol Oceanogr 52:456-469 